\title{
Paradiplomacy and Indonesian Public Diplomacy
}

\author{
Sri Issundari \\ Doctorate student of International Relations Departement \\ Universitas Padjadjaran Banung \\ Issundari.ari@gmail.com
}

\begin{abstract}
This article assumes the activities undertaken by paradiplomacy can be one way to support public diplomacy. Paradiplomacy is an extension of the authority of loval governments in the form of international relations activities. Actually, local governments have the authority in administration and governance at the provincial or district level in order to improve the welfare of local communities. Therefore, the cooperation undertaken is limited to cooperation between regions within the context of the state. The existence of globalization and democracy affect the pattern of international interaction that is no longer solely oriented to the state, but also the participation of non-state actors. In the context of public diplomacy, the central role government began to shift and be replaced by nonstate actors as agents. The relations established by non-state actors in the form of regions with counterpart can improve the network of economic, social, cultural and educational cooperation. Increased regional international cooperation can foster emotional closeness, avoid misperceptions and even further support foreign policy. The study was conducted on two international cooperation conducted by local government in Yogyakarta-Kyoto and Bandung-Braunshweig. From research conducted on both cities indicates that the continued existence of international cooperation by local government can encourage the closeness and appreciation of the outer public within the framework of Indonesian public diplomacy.
\end{abstract}

Keywords: paradiplomacy, international cooperation, local government, public diplomacy

\section{INTRODUCTION}

Since the Law No.22/1999calledthe regional autonomy policy was introduced, regions have an opportunity in implementing the international relation. Furthermore, Article 32 Law 2004 mentions the power division between central government and regional government asserted that the diplomacy can be done by the regional government is in the economic, social, culture, education, and so forth.

Yogyakarta and Bandung are cities in Indonesia that conduct international cooperations actively. Their involvement in international cooperation is one of form of subnational (regional) involvement in doing international relation, commonly referred as
Paradiplomacy [1]. Before regional autonomy was introduced, these two regions had already initiated international cooperation with overseas cities, such as Yogyakarta and Kyoto, Japan in 1985 [2] and also Bandung and Braunsweig, German in 1960 [3].

The international cooperation held by both cities is a form of communication and information sharing that can affect to mutual appreciation, even in a broader context, it can result output for both to solve common problems in the framework of peace. It is also one form of complementing Indonesian public through subnational as agent of public diplomacy. This article will describe the roles of paradiplomacy in supporting state's public diplomacyby raising cases of international cooperation Yogyakarta-Kyoto and Bandung-Braunsweig.

\section{INTERNATIONAL COOPERATION OF YOGYAKARTA-KYOTO AND BANDUNG- BRAUNSWEIG IN A FRAME OF INDONESIAN PARADIPLOMACY}

Paradiplomacy according to Duchachek is the involvement of constituent units (local/regional or subnational) in international activities [1]. It is also Andre Lecour who prefers the term subnational government with the name of secondworldthat refers to non-state actors who have no legitimacy in terms of sovereignty[4].

There are two trends that encourage paradiplomacy: first, external factors, the increasing of integration between countries as well as the emergence of supranational and regional blocks. Second, the internal factors, the existence of government decentralized system that gives greater authorities to regional government [6]. The involvement of subnational in international relation is inevitable. Nevertheless, the scope of such involvement is in the context of 'low politics' that involves non-traditional cooperation such as economic, social, culture, education, environment, and so forth[7].

The subnational involvement in international relation aims to increase the local potential and to solve the problems in local level. There are many advantages gained from the subnational involvement in international relation. For example, the US state administration is progressing rapidly in international relation after many international relations activities. In 1985, 29 states in the Unites States have 55 pemanent offices in 17 countries whereas in 1970 there were only 4 countries. It also notes that 18 port authorities in the US have 46 permanent 
mission in 11 countries [1]. In addition, the regionals encouraged to be active in solving international problems, for example in the State of California under Governor of Gray Davis forming a secretary of foreign relation at the local level to organize meetings with British prime minister, Israel, Greek, as well as meeting with Palestine leaders[8]. The increasing activities of paradiplomacy recently shows that there is no boundaries between international and domestic issues therefore the regional activities in international relation becomes necessity. In this case she state is no longer dominant in international relations. International cooperation is no longer a state authority because subgovernment can be involved in it [5].

Yogyakarta and Bandung are intensive cities in conducting international relations. Both cities utilize the cooperation that has been held to benefit for local welfare. One of them is the international cooperation of Yogyakarta-Kyoto and Bandung -Braunsweig cooperation. Cooperation of Yogyakarta with prefecture Kyoto has been implemented since 1985. The cooperation covers various fields including: in sending officers to study technical conservation of environmental conservation of cultural heritage objects, accepting the expert officers from Kyoto to help restoration of cultural heritage in Yogyakarta caused by earthquake; students exchange; competitions and exhibitions in order to exchange the painting of Yogyakarta-Kyoto children; accepting of tourism experts to give marketing training; conducting promotion of handicraft and so forth [2][9].

Meanwhile, the international cooperation between Bandung-Braunsweighas been established since 1960.It covered several activities including adolescent exchange; visiting program; economic and trade programs,promoting West Java culture in the Harz und Heideexhibition since 1974-1997, and World Expo event in Hannover andBaunschweigh, building GelanggangGenerasiMuda (Young Generation Arena), makingCikaudung River became cleaner through survey initiated by Braunsweigh City and conductingstudents exchange in high school and higher education level every year [3]. Those cooperationsare to reduce misperception, build mutual understanding, open the potential and needs of the region, and provide networking to be more active in international cooperation.

\section{THE ROLES OF PARADIPLOMACY IN SUPPORTING INDONESIAN PUBLIC DIPLOMACY}

Public diplomacy is one of strategies used by the state to increase influences in doing foreign relation through 'soft power' approach. Soft power' works by convincing people to follow or to agree on norms and institution in producing the desired behavior compared to use force [10]. It involves a large number of community groups from various background and various activities beyond the current government [11]. Therefore, the function of public diplomacy is to engage the public through nonpolitical initiatives and to influence public opinion to support its policies.
Public diplomacy is not only correlated with policy support and enhancing the image of the state through persuasive action. It is about building relationships; understand other countries, cultures, and societies; communicating different points of view; correcting misperceptions; and searching for areas where it can be solved together [11]. According to Jan Melissen, public diplomacy is based on listening to "other", that is about dialogue rather than monologue, and not only for shortterm policy objectives but also long-term relationship building [12]. Public diplomacy is no longer limited to deliver the policies, values, and norms persuasively from the state to the public, but also to establish relationships in order to solve problems together through two-ways dialogue.

The involvement of non-governmental agencies is part of the involvement of non-state actors in spreading public diplomacy.It is a collaborative public diplomacy by integrating non-state actors in implementing it [13]. They engage actively in international relations by supporting the diplomacy of the state whether intentionally or not. According to Jiang Wang, the role that subnational plays in supporting public diplomacy is to seek common understanding and to build mutually beneficial subnational cooperation described in the following dimensions of public diplomacy [14].From the figure 1 below shows that the third dimension of public diplomacy objective and levels of engagement is to build relationships made by subnational governments to achieve mutual understanding.

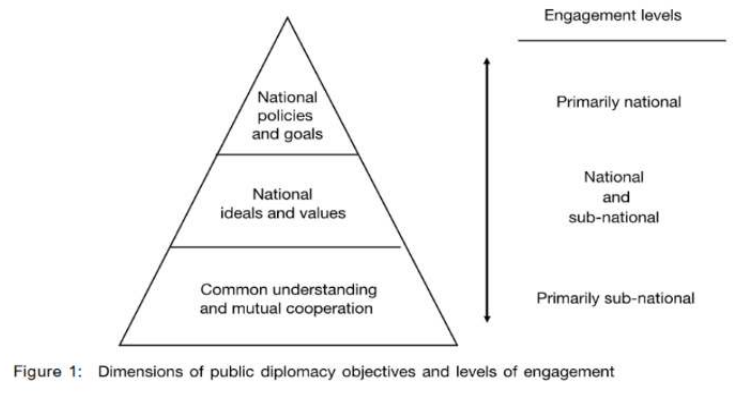

Figure 1

The Dimension of public diplomacy objectives and levels of engagement (Source: Jiang Wang, (2006). Localising Public Diplomacy the Role of Sub-national Actor in NationBranding. Place Branding, 2(1), 32-42)

Public diplomacy is initiated in Indonesian foreign policy since 2002. It is aimed at two objectives. The first is to present a moderate, democratic and progressive new faces of Indonesia, while the second ones to build diplomatic constituencies by collaborating and embracing all circles [15].

The subnational efforts in implementing Indonesian public diplomacy is to show the moderate Indonesian face that it refers to pluralistic of traditional and contemporary cultural art and tolerant of Indonesian society. They can co-exist without merging each other's 
identity. Introducing Javanese and Sundanese culture are ways to show Indonesia moderate face. Both subnational routinely disseminate their multicultural values through local cultures, for example: in 2010 a collaborative Art performance was held by Kraton (Palace) Yogyakarta dancers with gamelan players and Kyoto Prefecture performed at Ritsuimekan University and Kyoto City Center (Kyoto Station) for commemorating the $25^{\text {th }}$ anniversary of the Yogyakarta-Kyoto relationship and Gamelan Performance at Inamori Hall at Kyoto Pulse Plaza in order the $26^{\text {th }}$ National Cultural Festival of Japan attended by 300 Kyoto residents. [2][9]. While in year 2000 and 2017Bandung City hold Little Bandung Festival in Braunschweig city to promote creative industries, culinary snacks from Bandung, culture and tourism exhibition[16].

Disseminating local values to counterparts is one way of public diplomacy to attract sympathy and trust from partners. Trust and appreciation can only be built through relationship building that usually lasts long [11]. The effort to introduce local culture to the public abroad will encourage emotional closeness and mutual appreciation among the various parties so as to encourage them to respond positively to state policy. Within the success the city of Bandung-Braunsweigand Yogya-Kyoto in establishing communication in a long time boost emotional closeness and furtherly enhance in the form of collaboration and international cooperation. The cities of Yogyakarta and Kyoto enhance their relationship through the cultural collaboration of Yogyakarta and Kyoto in the form of traditional Japanese Nishijin weaving craft and Yogyakarta Batik cloth was named Kyoto NishijinYogya Anthology and was exhibited in the Kyoto, Jakarta and Yogyakarta since 2000 to 2008 [17]. The collaboration through the cloths shows the emotional closeness and even both subnational willingness to adapt their culture to a product that illustrates a mixture of Javanese and Japanese cultures.

The other Yogyakarta's support for Indonesian public diplomacy is also manifested through dialogue efforts to support international peace in the form of Yogyakarta's involvement in the League of Historical Cities (LHC) centered in Kyoto. The closeness of Yogyakarta and Kyoto offers a network for Yogyakarta to join the international organization. The League that was founded in 1994 was formed with the aim to contribute to world peace. Yogyakarta through LHC is committed to building the foundation and strengthening the bond between the historic cities in the world. The League produced a joint declaration stating that differences are not a barrier for cities in the world to build a shared commitment to achieve a common goal, world peace and the development of historic cities[18]. The involvement of Yogyakarta in the LHC shows a great contribution from Indonesia in supporting international peace in the form of strengthening the bonds between international historical cities in the world.

Subnational is very potential to support Indonesian public diplomacy. If public diplomacy aims to disseminate values, build dialogue and solve problems together then subnational will play the role of implementing that goal by building closer relations and cooperation with abroad partners. Subnational involvement in supporting public diplomacy is a manifestation of the domestic dimension from civil society participation in public diplomacy[19]. The activities done by Yogyakarta and Bandung through their cooperation with counterparts is one form of parallel domestic dimension in public diplomacy where paradiplomacy activities are agent of public diplomacy. The partnership between Yogyakarta and Bandung and its partners provides a network for Indonesian public diplomacy to enhance dialogue and networking of cooperation with various foreign parties through subnational channels. In the long term, the existence of understanding and the emotional closeness of foreign partners towards Indonesia can give influence in the form of support to Indonesian foreign policy.

\section{CONCLUSION}

Subnational is one of the non-state actors that hasan important role in supporting the state's public diplomacy by encouraging the efforts to bond emotional closeness and mutual understanding through the activities undertaken by paradiplomacy. International activities conducted by Yogyakarta-Kyoto and BandungBraunsweigare examples of paradiplomacy efforts in supporting Indonesian public diplomacy. The intensity of activities conducted by both subnational and its counterparts over a long period of time can lead to the closeness and appreciation that are useful in shaping a positive international society in response to Indonesia's foreign policy.

\section{ACKNOWLEDGMENT}

Author would like to thanks to the LPDP program that funds the author in participating in this International seminar through LPDP scholarship 2016.

\section{REFERENCES}

[1] I. Duchacek, "The International Dimension of Subnational Self-Government," Publius: The Journal of Federalism, vol. 14, pp. 5-31, 1984.

[2] Badan Kerjasama Setda Provinsi DIY, "Laporan Monitoring Evaluasi Kerjasama Luar Negeri," Badan Kerjasama Setda Provinsi DIY, Yogyakarta, 2008.

[3] Secretariat, Section of Public Administration of Bandung, 2008.

[4] A. Lecours, "Paradiplomacy: Reflections of Foreign Policy and International Relations of Regions," in International Negotiation, 2002, pp. 91-114.

[5] D. Josselin and W. Wallace, Non-State Actors in the Word Politics, vol. 1, New York: Palgrave Publisher, 2001.

[6] R. Martinez, "Paradiplomacy in North America: canadian Provinces' Relations with Their US and 
Mexican Counterparts," Nortamerica, vol. 12, no. 2, 2017.

[7] M. J. Keating, Paradiplomacy in Action: The Foreign Relations of Subnatioal Government, London: Frank Cass \& Co, 1999.

[8] S. L. McMillan, "Subnational Foreign Policy Actors: How and Why Governors Participate in US," Foreign Analysis, vol. 4, no. 3, pp. 227-273.

[9] T. A. Mukti, Kerjasama Luar Negeri oleh Pemda di Indonesia, Yogyakarta: The Phinisi Press, 2013.

[10] J. S. Nye, "Soft Power," Foreign Policy, vol. 80, pp. 153-171, 1990.

[11] M. Leonard, Public Diplomacy, Foreign Policy Centre, 2002.

[12] J. Melissen, Netherlands Institute of International Relations "Clingendael", The Hague, 2011.

[13] A. Fisher, Collaborative Public Diplomacy, New York: Palgrave MacMillan, 2013.

[14] J. Wang, "Localising Public Diplomacy: The Role of Sub-national Actors in Nation Branding," Place Branding and Public Diplomacy, vol. 2, no. 1, pp. 32-42. /07/membangun-citra-indonesia-yang-demokratismoderat-dan-progresif-melalui-diplomasi-publik/ accessed on 8 De. [Online]. [Accessed 8 December 2017].

[16] "Konsulat Jenderal RI "Little Bandung Festival" Perkuat Kerjasama Sister City BandungBraunsweig,"

https://www.kemlu.go.id/hamburg/id/berita-agenda/ berita-perwakilan/Pages/little-bandung-festivalperkuat-sister-city-bandung-braunschweig.aspx a, 2017. [Online]. [Accessed 8 December 2018].

[17] "Pameran Te-Collabo : Sebuah Kolaborasi Teknologi," http://www.tuugo.net/SiteViewer/0160003012826? , [Online]. Available: http:\%2F\%2Fwww.eastjavatraveler.com $\% 2 \mathrm{~F} \% 3 \mathrm{Fp}$ \%3D496. [Accessed 20 December 2017].

[18] "member cities of Asian," http:// www2. city.kyoto.lg.jp/somu/kokusai/lhcs/. [Online]. [Accessed 20 December 2017].

[19] E. Huijgh, "Public Diplomacy in Flux: Introducing the Domestic Dimension," The Hague Journal of Diplomacy, vol. 7, pp. 359-367, 2012.

[15] "Membangun Citra Indonesia yang Demokratis, Moderat dan Progresif Melalui Diplomasi Publik," http://www.tabloiddiplomasi.org/index.php/2017/07 